S sciendo International Conference KNOWLEDGE-BASED ORGANIZATION
Vol. XXVII

\title{
ANALYSIS OF FACTORS AFFECTING ON THE SENSE OF SAFETY IN LOCAL COMMUNITIES
}

\author{
Marlena NIEMIEC, Karina GÓRSKA-ROŻEJ \\ War Studies University, Warsaw, Poland \\ m.niemiec@akademia.mil.pl, \\ k.rożej@akademia.mil.pl
}

\begin{abstract}
The aim of the article was the analysis of the factors that may affect on the sense of safety in local communities. The method applied in the article was a diagnostic survey using questionnaires as a technique and a questionnaire which was used as a tool for collecting the empirical data. The obtained data made it possible to solve the research problem (presented in the article) and to demonstrate, in an innovative way, the relation between factors such as: contact with relevant services, information campaigns, preventive measures and the elimination of people at risk of social pathologies as those that affect on the safety of the local community. The results of the research show that respondents are aware of the presence of certain factors in their local environment as well as see their impact on the functioning in the local community and they know about factors which have a significant impact on their sense of security in the context of functioning in the local community.
\end{abstract}

\section{Keywords: sense of security, local community, guards}

\section{Introduction}

Each of us functions in a specific local community. The commonly related term that often occurs when we start thinking about local communities is the term of feeling secure. The concept of it is rather used as a psychological basic. Therefore, for the purpose of the article, several factors influencing the sense of security in local communities were identified (the most important in the authors' opinion). We can talk mainly about wide-understood social pathologies, such as: alcoholism, domestic violence, drugs addiction, ensuring public order as a result of the Municipal Guard, Police action or assuring fire protection and sanitary safety or combating the effects of natural disasters. It is worth to mention the preparation and development of preventive measures that has to present the occurrence of dysfunctions various types within local communities which has a direct impact on functioning in local communities. For this article, the authors focused on selected factors only, which (in authors' opinion) may significantly affect on the sense of security in local communities and the people living there.

\section{Local community and sense of safety - a theoretical approach}

Safety of the local communities is a basis for proper functioning not only for individual residents and small communities but also determine the condition of countries in a global perspective. Satisfying one of the basic human needs, which is the sense of security, requires a number of undertakings. One of the most effective tasks, although not the easiest one, is to carry out the preventive action to prevent adverse phenomena. Often, the effects of such activity are visible only 
after years and at the same time, it requires Multi-directional activities which involve various entitles. The safety of the local community includes a number of important elements that affect the quality of life and health of the inhabitants [1]. Therefore, the security is an objectified state of no danger, integrally related to the subjective, emotional and psychological perception of space as a safe one or as a sense of security. In the institutional dimension, the sense of security can be defined as "all social conditions and institutions that protect the state and citizens from phenomena that are dangerous to the legal order, life and health and also the one which causes large material losses. All organs of state authorities and administration are obligated to ensure public safety, especially the institutions specialized in ensuring public safety such as Police, Fire Brigades, etc." [2].

A characteristic feature of the local community is that it shapes strong local ties and local forms of organization of collective life. It seems that it is still one of the most important links in the system of social control of behavior and it has an important role in the processes of upbringing and socialization as well as maintaining the social-cultural side of life. Activities on a local scale are mainly based on the activity of the local community and cooperation with local partners. In the functioning of local communities, three most important elements are indicated: territorial community, mutual interaction and various forms of ties arising on the basis of similar situation which entourage actions, developing specific norms and defining goals and values [3].

While preparing preventive programs, more often rapid changes which take place in the types of threats and risky behaviors as well as the education about them are noticed. Prevention is also permanently related to safety. Considering safety as a process, attention is paid to its two stages: preventing threats and reacting to violation of the integrity of specific goods, which determines the hierarchy of detailed objectives and allow choosing effective methods. The need of security can be satisfied through preventive measures and intervention and compensation measures. The problem of social sense of security and the factors which determine its level should be considered in the system of relations between the institution dealing with the protection of public order and safety and the level of crime threats. Such institutions are: local government, Police, Guards, schools, non-profit organizations and entities that are involved in carrying out preventive projects in their activities. In the preventive action the bond is an important element that should be included in these interactions. Using its strength in belonging to important groups may cause integration of some of these activities in selected programs. Due to it all, it can be assumed that the social bond may be one of the important elements in shaping safety with the use of prevention in the local community [4].

Into the basic stages which attend the creation of prevention strategy of terrorist threats (education, information and intervention) we can include: analysis of the actual state of threats in the environment, defining the goals of the main programs and indirect goals, indication of program receivers, indication of people and institutions which are responsible for the preparation and the implementation of programs, defining detailed activities projects and the time of its implementation, an indication of the responsible entities for the programs and the method of communicating with the target group, indication of the sources of financing strategic/program activities, presentation of program assumptions and implementation of programs, monitoring, assessment and evaluation of the preventive strategy and its programs [5]. As it can be seen from the above considerations, the concepts of security and a sense of security are closely related to local communities and 
functioning in it on various levels. Of course, an equal important element in relation to local communities is the preventive programs and activities which are responding to the needs of local communities.

\section{Analysis of the results of own research}

For the present article, a research was conducted. The diagnostic survey method was used, the technique applied was questioning and the tool was a questionnaire. The research was carried out as a part or scientific-and-research work about Safety attributes of the administration of safety management in the perspective of local communities. 600 people took part in the research and the adopted criterion for selecting respondents was related to their place and residence. The respondents were selected from the following locations: Siedlce (16\%), Włocławek (16\%), Zamość (17\%), Piła (17\%), Ostrów Wielkopolski $(17 \%)$, Zgierz (17\%). The main research problem that had to be solved in the context of this article came as a question: What is the impact of contacts with uniforms services, preventive actions, information campaigns and elimination of social pathologies on the sense of security in the local community?

The collected empirical data that allow to get an answer to the above research problem have been presented in an aggregate form on the charts which illustrate the examined factors and phenomena.

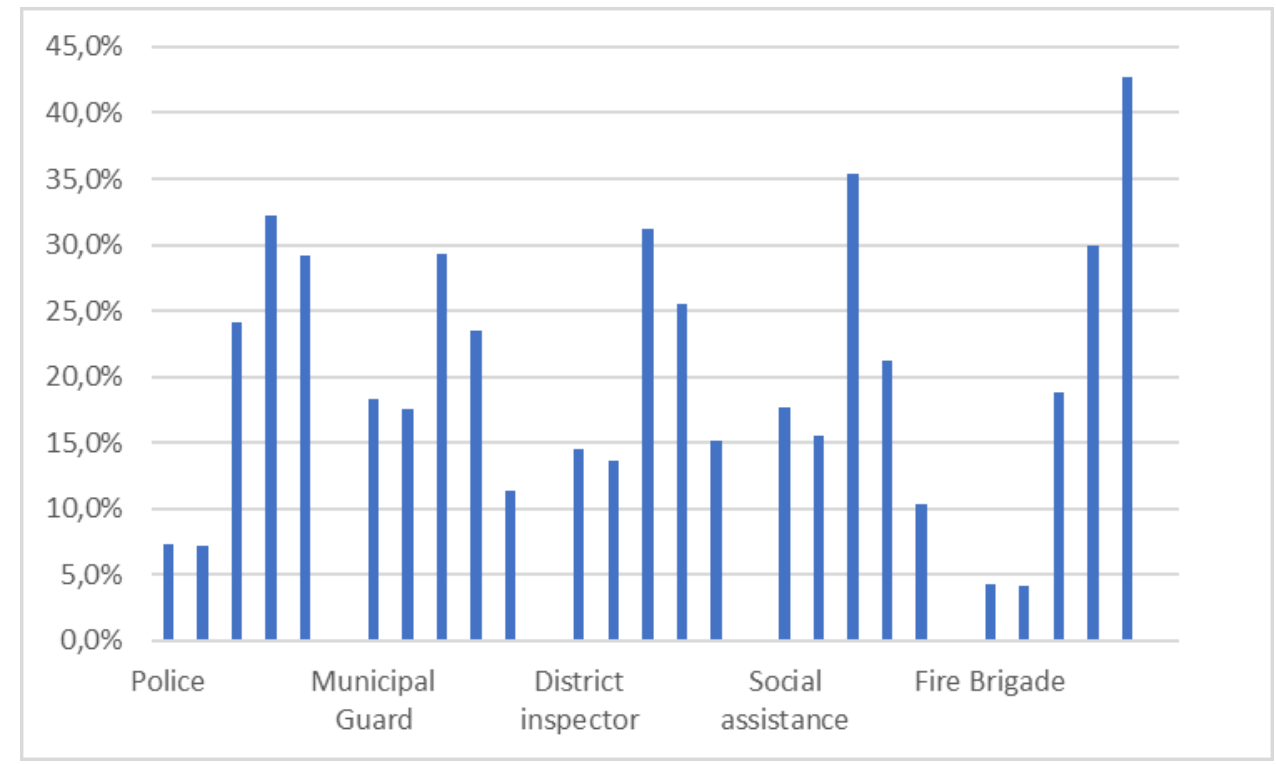

Figure 1: Contact with services and the sense of security

Source: own research.

In the context of the responses (Figure 1), in relation to the Police as an element which influence the sense of security in the local community the responses were as follows: $32 \%$ of respondents considered that contact with the Police is an important element of shaping their sense of security in the local community, for $29 \%$ respondents - it is an important aspect, for $24 \%$ - an average aspect, for $8 \%$ and $7 \%$ property: not so important and unimportant. Concerning the contact with the Municipal Guard, the respondents assessed this contact as influencing their sense of security in the following way: $29 \%$ respondents assessed it as an average important aspect, $24 \%$ respondents indicated that this contact is important, for 
$18 \%$ it is not so important or an unimportant aspect, for $11 \%$ respondents this contact is important in the context of shaping their sense of security in the local community. In the context of the question about the District inspector, the answers were as follows: for $31 \%$ of respondents this factor is assessed as moderately important, for $26 \%$ it is important and for $15 \%$ it is a very important element. For $15 \%$ and $14 \%$ of respondents it is, property, not so important and an unimportant factor. In reference to the contacts with the social assistance, respondents answered as follows: for $35 \%$ it is an aspect which is average important in shaping sense of security in the local community, for $21 \%$ it is an important factor, for $18 \%$ unimportant, for $16 \%$ - not so important and for $10 \%$ it is set as a very important factor. In the context of the responses in relation to the Fire Brigade, the responses were as follows: for $43 \%$ of them, the contact with the fire brigade is very important in shaping the sense of security in the local community, $30 \%$ of respondents indicated that this is an important factor, for $19 \%$ - average importance, for $4 \%$ it is a factor not so important and unimportant. Summing up this part, it can be concluded that among the various services that may have a significant impact on the sense of security in local communities, the most frequently indicated one was the Fire Department, followed by the Police (which has great trust among the respondents) and the Municipal Guard. In relation to the Municipal Guard, the social assistance and the District inspector, respondents indicated that the influence of these services on their sense of security in the local community is slightly smaller.

In the process of collecting the empirical data, respondents were asked about the general factors that have influence on their sense of security in local communities. In the context of preventive activities in the local community, respondents indicated that as many as $39 \%$ of them believe that it is an important factor, for $29 \%$ it is an average important factor and $22 \%$ considered it to be a very important factor. In the amount of $7 \%$ of the respondents it was indicated as low importance and for 3\% the importance is very low. In regard to the information campaigns which may be carried out in the local environment, respondents indicated that this is an element which is important for $37 \%$ respondents, for $30 \%$ of them it is of average importance and for $23 \%$ of respondents it is a very important factor, if it comes about their sense of security. In the case of $8 \%$ of the respondents, it was indicated that this is not an important factor, and for $2 \%$ - very low. In the context of the question about effective interventions of services, the answers were as follows: for $41 \%$ of respondents it is a very important factor, for $31 \%$ of respondents it is a highly rated element (so as important), for $22 \%$ - it is a factor of average importance, while for $5 \%$ of respondents it is a factor not so important and for $1 \%$ - unimportant. Regarding the question about the availability of services in local communities, the answers were as follows: for $37 \%$ of respondents this element is very important (in the context of their sense of security), for $34 \%$ - it is an important element, for $23 \%$ of respondents it is an average important factor and for $4 \%$ it is not so important, while for $2 \%$ of respondents it is unimportant. Regarding the question about the elimination of people at risk of social pathologies from the local environment, answers were as follows: for $34 \%$ of respondents it is an average important factor, for $24 \%$ it is (respectively) a very important and an important factor, for $10 \%$ it is less important, and for $4 \%$ of respondents - unimportant. Summing up this part, it can be concluded that the respondents considered that such elements such as: preventive measures, information campaigns, effective intervention of services and wider access to services are the 
elements that may affect on their sense of security in local communities. For respondents, the less meaning had the elimination from the local community people of the risk of social pathologies, such as: alcoholism, drugs addiction, violence and others. The reason may be perceived as the fact that respondents live in places where there are for, example (among others) military units. It can be concluded that the presence of military units influences the increasing of the sense of security in the local communities, so the inhabitants do not perceive the social pathologies as a strong threat to their sense of security. Summing up, it can be stated that all discussed factors, such as: contact with services, preventive measures, promotional campaigns, effective interventions of services, wide access to this services and, in minimum, elimination of people at risk of social pathologies from local communities, have an impact on their functioning in that environment.

\section{Conclusions}

Summarizing the considerations in relation to the factors that affect on the sense of security in local communities, it can be stated that these are the factors such as cooperation between services like: Police, Fire Brigade, Municipal Guard, District inspector and Social assistance. Without any doubt, other factors are important as well, such as: preventive measures, information campaigns, interventions of services and access to these services, as well as the elimination of people at risk of social pathologies from the local environment. The conclusions based on the analysis of the collected empirical data allow to conclude, that there are a lot of factors that affect the sense of security in local communities and that intensification of the activities of services and development of appropriate activities (such as: information and preventive ones) may significantly contribute to the increase of the sense of security.

\section{References List}

[1] Mucha B., Mucha M., Safety of the local community as an element of quality of life in the light of the activities of the City Guard in Jelenia Góra. In: Nowak W., Szalonka K., Zdrowie i styl życia. Wyzwania ekonomiczne i społeczne. Wrocław. Publisher: UW; 2019. p. 371.

[2] Bogacka E., Siniecka A., Poczucie bezpieczeństwa mieszkańców miasta. Przykład Poznania. In: Rozwój Regionalny i Polityka Regionalna, 2016, 33. p. 57.

[3] Potoczek A., Bezpieczenśtwo jako obszar zarządzania jednostką terytorialną. Toruń. Publisher: KJ; 2018. pp. 161-163.

[4] Mazur J., Prevention in the Local Community as Counteracting Threats - Supporting Factors and Barriers. Sociological Reflection. In: Wilk-Woś Z., Bezpieczeństwo i zarządzanie kryzysowe. Bezpieczeństwo społeczności lokalnych. Łódź-Warszawa. Publisher: SAN; 2017. p. 38, pp. 41-42, p. 47.

[5] Kopczewski M., Bednarczyk W., Niedźwiecki S., Preventive Programs as a Security Element at the Local Level. In: Wilk-Woś Z., Bezpieczeństwo i zarządzanie kryzysowe. Bezpieczeństwo społeczności lokalnych. Łódź-Warszawa. Publisher: SAN; 2017. p. 38, pp. 62-63. 